Review Article

\title{
Prevalence of Hypertension in Indian Tribal Adult population: A Scoping Review
}

\author{
Nalini Tripathi', Jugal Kishore ${ }^{2}$, Bontha V Babu ${ }^{3}$ \\ ${ }^{1}$ Scientist-C, ICMR Project, Dept.of Community Medicine, VMMC \& Safdarjung Hospital, New Delhi, India. \\ 2Director-Professor and Head, Dept. of Community Medicine, VMMC and Safdarjung Hospital, New Delhi, India. \\ ${ }^{3}$ Scientist-G, Indian Council of Medicla Research, New Delhi, India. \\ DOI: https://doi.org/10.24321/2349.7181.202002
}

\section{I $\quad \mathbf{N} \quad \mathbf{F} \quad \mathbf{O}$}

\section{Corresponding Author:}

Dr. Nalini Tripathi, ICMR Project, VMMC \& Safdarjung Hospital, New Delhi.

E-mail Id:

neha.nalini@gmail.com

Orcid Id:

https://orcid.org/0000-0002-1159-8672

How to cite this article:

Tripathi N, Kishore J, Babu B. Prevalence of Hypertension in Indian Tribal Adult population: A Scoping Review. J Adv Res Med 2020; 7(1): 5-13.

Date of Submission: 2020-06-02

Date of Acceptance: 2020-07-15

\section{$\begin{array}{llllllll}\mathbf{A} & \mathbf{B} & \mathbf{S} & \mathbf{T} & \mathbf{R} & \mathbf{A} & \mathbf{C} & \mathbf{T}\end{array}$}

Background: There is an increasing trend in prevalence of hypertension worldwide. Studies have shown that tribal populations in India are also experiencing this transition.

Objective: To know the prevalence of hypertension in tribal population of India.

Method: A literature search PubMed, Google scholar databases from January 1980-December 2019 using the MeSH (Medical Subject Heading) - prevalence, hypertension, tribal, adult population, India, cross-sectional studies was conducted. Out of the total 96 published studies which reported the prevalence of hypertension in Indian tribal population, 21 were included in the review.

Data Extraction: All the data were extracted by the investigators using a standardized protocol and data collection form.

Result: Total twenty-one studies with sample size varying from 154 to 47,401 were included in the review. The reported prevalence of hypertension in tribal populations varied from $10 \%$ to $55.5 \%$ in different regions and states of India. The prevalence of hypertension in males was higher than females. Increasing age, body mass index, smoking, diabetes and extra salt intake were common risk factors.

Conclusion: The prevalence of hypertension in Indian tribal population is as high as other urban and rural populations and needs preventive measures to control the problem.

Keywords: Hypertension, Prevalence, Tribal Population, India

\section{Introduction}

Hypertension (HTN) is a major public health problem and a leading Non-Communicable Disease (NCD) in India. It is estimated to be attributable to nearly 10 percent of all NCDs. The prevalence of hypertension in adults increased over the past 25 years from $5 \%$ to $20-40 \%$ in urban populations and $12-17 \%$ in rural populations. ${ }^{1}$ Globally, HTN affects about 1 billion people and it is estimated that by 2025 , up to 1.58 billion adults worldwide will suffer from complications of HTN. ${ }^{2}$ The high prevalence of HTN makes it a significant 
factor for mortality and morbidity. ${ }^{3}$ The prevalence of HTN varies widely across the countries. Various studies conducted in India in the last two decades showed that hypertension is increasing both in urban ${ }^{4}$ and among rural communities. ${ }^{5,6,7}$ Apart from these studies, small studies have also been conducted on the prevalence of HTN in tribal population. Within Indian context, tribal population, restricted to remote hilly terrains, are associated with poverty, illiteracy, malnutrition. ${ }^{8}$ Thus, they are assumed to be untouched by hypertension, which is lifestyle driven disease. However, recent studies have produced evidence for increasing trend of hypertension among tribal population. ${ }^{9}$

According to census 2011, the Scheduled Tribe (ST) population of India is, 104.3 million, which constitutes $8.6 \%$ of the total population ${ }^{10}$ and about $90 \%$ of tribal lives in rural areas and only $10 \%$ live in urban areas. In broader terms they inhabit two distinct geographical areas i.e Central India and North Eastern India where more than half of the tribal population are present in Central India; i.e. Madhya Pradesh (14.7\%), Chhattisgarh (7.5\%), Jharkhand (8.3\%), Andhra Pradesh (5.7\%), Maharashtra (10.1\%), Orissa (9.2\%), Gujarat (8.6\%) and Rajasthan (8.9\%). ${ }^{11}$ Tribal populations are less accessible for routine scientific studies because of their scattered habitats, inaccessible terrain, and nomadic nature of living. Therefore, it is important to systematically quantify the available data from various cross-sectional studies conducted in India. We conducted a systematic review to estimate the prevalence of hypertension among adults of various tribal groups in India for the period 1980 to 2019, and to evaluate the changing trends in HTN prevalence by region and gender.

\section{Methodology}

A study protocol was prepared and predefined the data sources, search strategy, study eligibility criteria, quality assessment and data extraction of the studies. HTN is defined as systolic Blood Pressure (BP) of at least $140 \mathrm{mmHg}$ and or diastolic BP of at least $90 \mathrm{mmHg}$. The guidelines under PRISMA Statement for Preferred Reporting Items for Systematic Reviews and Meta Analyses were followed during undertaking this systematic review. ${ }^{12,13}$

\section{Literature Search Strategy}

We performed a systematic review from Google Scholar and PubMed using advanced search with key words 1. Hypertension 2. Prevalence 3. Tribal 4. India. The following MeSH terms was also used: (a) search 1: BP or high-BP; (b) search 2: Indian tribal and adult population and (c) search 3: search 1 and search 2 . We included studies conducted among adult Indians with HTN and published in the English language during January 2008 to December 2019. We also carried out extensive hand searches and contacted authors for further information. Cross references of all selected articles were scanned for additional studies. We screened table of contents of journals which were likely to publish such studies. To obtain disaggregate data, at least two email requests were sent to the corresponding author. If more than one article was published from a study, the article that provided the most updated data was selected.

\section{Study Selection}

The literature was searched using the pre-specified strategy. We eliminated duplicates using the Reference Manager Software version 12 (Thomson Reuters, New York). The type of studies in our review includes cross-sectional studies. We excluded the articles which do not have access to full length article. Reviews, case series, individual case reports, editorials, short communications and commentaries are excluded because they did not have original data or outcome data to provide meaningful conclusions. We also excluded some abstracts, which were not related to the study. We did not include studies on Indians staying outside India because in this set of population the exposure to the environmental and risk factors will be different as compared with those Indians (most of them were IndoAmerican studies) living in India.

\section{Quality Assessment and Data Extraction}

Using appropriately modified critical appraisal checklists, each article was assessed for quality assessment. We extracted data from full-length articles wherever available. We included abstracts only when they had sufficient data. Study characteristics (first author, place of study, year of publication and study population) participant characteristics (age group and tribe name, and prevalence of HTN were extracted onto pre-coded spreadsheets. Data were extracted at the lowest possible disaggregate level (referred to as major tribal population here).

\section{Statistical Analysis}

Estimates of prevalence indicated as proportions. Trends for prevalence of hypertension were recorded for sex, age, gender, and region, and arranged the studies since 2008 onwards.

\section{Result}

\section{Search Result}

Of the total 96 articles, 86 articles were considered for review and 10 duplicates articles were removed. Among these studies, only 21 articles ${ }^{14-34}$ were considered for data extraction (Figure 1). 


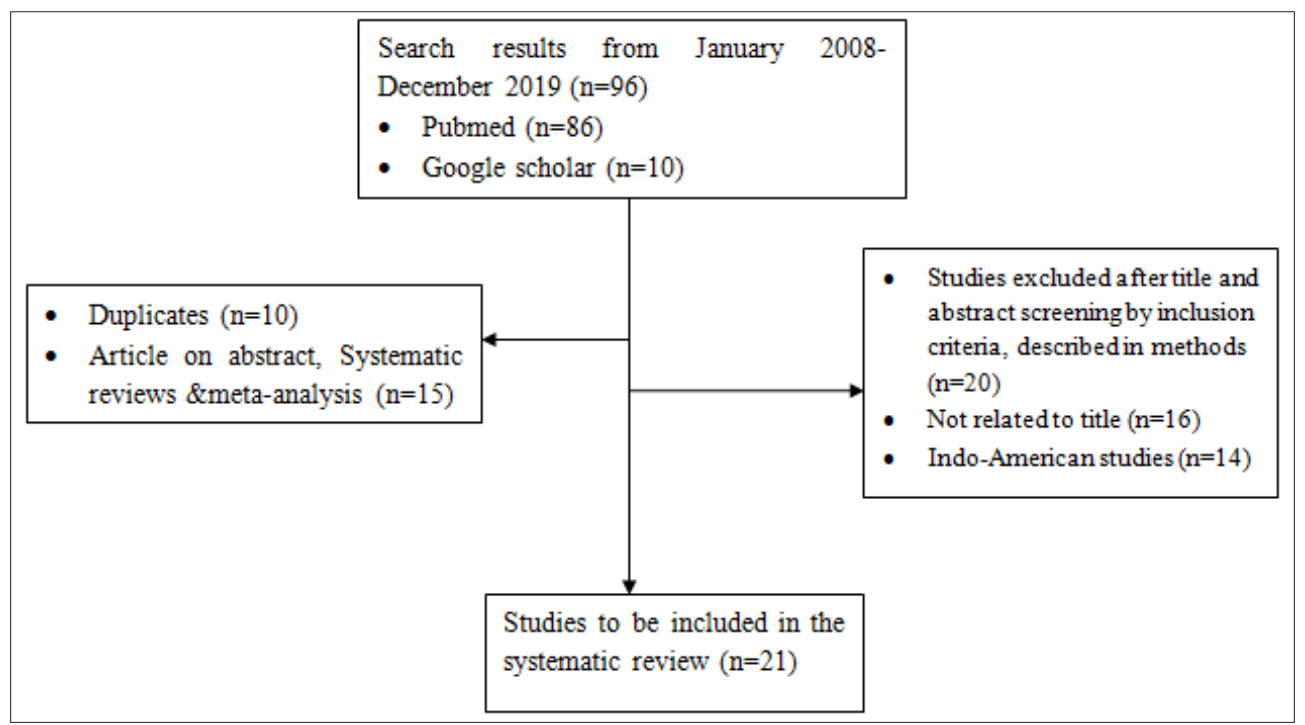

Figure I.Flow chart providing the number of studies identified, excluded for various reasons and included in scoping review

Table I.Prevalence of hypertension observed in cross sectional studies in different parts of country

\begin{tabular}{|c|c|c|c|c|c|c|c|c|c|}
\hline \multirow{2}{*}{$\begin{array}{l}\text { S. } \\
\text { No. }\end{array}$} & \multirow{2}{*}{ First Author } & \multirow{2}{*}{ Year } & \multirow{2}{*}{$\begin{array}{l}\text { Age } \\
\text { (yrs) }\end{array}$} & \multirow{2}{*}{ Area/ Region } & \multicolumn{3}{|c|}{ Population (n) } & \multirow{2}{*}{ Tribes } & \multirow{2}{*}{$\begin{array}{c}\text { HTN Prevalence } \\
(\%)\end{array}$} \\
\hline & & & & & Total & Male & Female & & \\
\hline 1. & Tiwari $\mathrm{RR}^{14}$ & 2008 & $\begin{array}{c}20 \& \\
\text { above }\end{array}$ & Gujrat & 154 & 91 & 63 & $\begin{array}{c}\text { Naika } \\
\text { Rathwa }\end{array}$ & $\begin{array}{c}\text { Total-16.9\% } \\
\text { Male-16.5\% } \\
\text { Female-17.5\% }\end{array}$ \\
\hline 2. & $\begin{array}{c}\text { Manimunda } \\
\mathrm{SK}^{15}\end{array}$ & 2011 & $\begin{array}{c}20 \& \\
\text { above }\end{array}$ & $\begin{array}{l}\text { Car Nicobar } \\
\text { Islands }\end{array}$ & 975 & NA & NA & NA & Total-50.5\% \\
\hline 3. & Meshram II' & 2012 & $\begin{array}{c}20 \& \\
\text { above }\end{array}$ & Kerala & 4193 & 1891 & 2302 & NA & $\begin{array}{c}\text { Total }-40 \% \\
\text { Male-45\% } \\
\text { Female-36\% }\end{array}$ \\
\hline 4. & Hathur $\mathrm{B}^{17}$ & 2013 & $20-60$ & $\begin{array}{l}\text { Mysore, } \\
\text { Karnataka }\end{array}$ & 1290 & 571 & 719 & $\begin{array}{l}\text { Jenu } \\
\text { Kuruba }\end{array}$ & $\begin{array}{c}\text { Total }-21.7 \% \\
\text { Male-28.25\% } \\
\text { Female-16.5\% }\end{array}$ \\
\hline 5. & Meshram II & 2014 & $\begin{array}{c}20 \& \\
\text { above }\end{array}$ & Maharashtra & 4348 & NA & NA & NA & Total- 23\% \\
\hline 6. & Misra PJ 20 & 2014 & $\begin{array}{c}20 \& \\
\text { above }\end{array}$ & Assam & 332 & 179 & 153 & NA & Total-26\% \\
\hline 7. & Laximaiah $\mathrm{A}^{21}$ & 2015 & $\begin{array}{c}20 \& \\
\text { above }\end{array}$ & $\begin{array}{c}9 \text { states: } \\
\text { A.P., Gujrat, } \\
\text { Karnataka, } \\
\text { M.P., } \\
\text { Maharashtra, } \\
\text { Kerala, Odisha, } \\
\text { W.B., Tamil } \\
\text { Nadu }\end{array}$ & 47401 & 21141 & 26260 & NA & $\begin{array}{c}\text { Total-26.7\% } \\
\text { Male-27.1 } \\
\text { Female-27.4 }\end{array}$ \\
\hline 8. & Kumar $\mathrm{RK}^{19}$ & 2016 & $18-60$ & $\begin{array}{l}\text { Madhya } \\
\text { Pradesh }\end{array}$ & 300 & 127 & 173 & NA & $\begin{array}{c}\text { Total }-22 \% \\
\text { Male-32.3\% } \\
\text { Female-14.4\% }\end{array}$ \\
\hline
\end{tabular}




\begin{tabular}{|c|c|c|c|c|c|c|c|c|c|}
\hline 9. & Kandpal V22 & 2016 & $20-60$ & Uttarakhand & 288 & 104 & 184 & $\begin{array}{l}\text { Rang } \\
\text { Bhotia }\end{array}$ & $\begin{array}{c}\text { Total-43.4\% } \\
\text { Male-57.7\% } \\
\text { Female-35.3\% }\end{array}$ \\
\hline 10. & Raina $\mathrm{SK}^{23}$ & 2016 & $20-94$ & Uttarakhand & 401 & 270 & 131 & NA & $\begin{array}{c}\text { Total-10.7\% } \\
\text { Male-12.9\% } \\
\text { Female-6.0\% }\end{array}$ \\
\hline 11. & Negi $P^{24}$ & 2016 & $20-70$ & Kinnaur, H.P. & 3582 & 1632 & 1950 & NA & $\begin{array}{c}\text { Total-19.7\% } \\
\text { Male-22.4 } \\
\text { Female-17.5 }\end{array}$ \\
\hline 12. & Ksthriya GK ${ }^{25}$ & 2016 & $20-60$ & $\begin{array}{c}\text { West Bengal, } \\
\text { Odisha, } \\
\text { Gujrat }\end{array}$ & 2156 & 1066 & 1090 & $\begin{array}{c}\text { 1.West } \\
\text { Bengal } \\
\text { Tribes } \\
\text { (Santhal, } \\
\text { Oraons, } \\
\text { Koras) } \\
\text { 2.Odisha } \\
\text { Tribes } \\
\text { (Santhals, } \\
\text { Bhumijs, } \\
\text { Bathudis) } \\
\text { 3. Gujrat } \\
\text { Tribes } \\
\text { (Dhodias, } \\
\text { Kuknas, } \\
\text { Chaudhris) }\end{array}$ & $\begin{array}{c}\text { Total- } 10 \% \\
\text { In Tribes (\%) } \\
\text { 1.Santhal (W.B)- } \\
11.8 \% \\
\text { 2.Oraons-16.5\% } \\
\text { 3.Koras-10.6\% } \\
\text { 4.Santhal } \\
\text { (Odisha)-9.6\% } \\
\text { 5.Bhumis-14.7\% } \\
\text { 6.Bhathudis-12.1\% } \\
\text { 7.Dhodis-12.9\% } \\
\text { 8. Kuknas-11.3\% } \\
\text { 9.Chaudhris-11.3\% }\end{array}$ \\
\hline 13. & Chakma $\mathrm{T}^{26}$ & 2017 & $\begin{array}{c}20 \& \\
\text { above }\end{array}$ & $\begin{array}{l}\text { Madhya } \\
\text { Pradesh }\end{array}$ & 3090 & 1442 & 1648 & NA & $\begin{array}{c}\text { Total-19\% } \\
\text { Male-28.2\% } \\
\text { Female-23.6\% }\end{array}$ \\
\hline 14. & Deo MG ${ }^{27}$ & 2017 & $\begin{array}{c}18 \& \\
\text { above }\end{array}$ & Maharashtra & 410 & 191 & 219 & Katkari & $16.8 \%$ \\
\hline 15. & Sanjeev $\mathrm{P}^{28}$ & 2018 & $25-64$ & $\begin{array}{c}\text { Thiruvanant- } \\
\text { hapuram, } \\
\text { Kerela }\end{array}$ & 298 & 149 & 149 & Kani & $48.3 \%$ \\
\hline 16. & TushiA $^{29}$ & 2018 & $25-64$ & $\begin{array}{l}\text { Mokokchung, } \\
\text { Nagaland }\end{array}$ & 472 & 236 & 236 & NA & $43.2 \%$ \\
\hline 17. & Deo $\mathrm{MG}^{30}$ & 2018 & $18-60$ & $\begin{array}{l}\text { Western \& } \\
\text { Northern } \\
\text { Maharastra }\end{array}$ & 1864 & 904 & 960 & $\begin{array}{c}\text { Bhils }(\mathrm{BH}) \\
\text { Karkaris } \\
(\mathrm{KA}) \\
\text { Kokana } \\
\text { (KO) } \\
\text { Tkakars } \\
\text { (TH) }\end{array}$ & $\begin{array}{c}\text { Total- } 11.7 \% \\
\text { In tribes: } \\
\text { BH-11.9\% } \\
\text { KA-16.0\% } \\
\text { KO- } 13.7 \% \\
\text { TH-8.7\% }\end{array}$ \\
\hline 18. & $\begin{array}{c}\text { Kshatriya } \\
\text { GK }^{31}\end{array}$ & 2019 & $20-60$ & NA & 2156 & 1066 & 1090 & NA & $\begin{array}{c}\text { Total }-11.7 \% \\
\text { Male-9.3\% } \\
\text { Female-14.2\% }\end{array}$ \\
\hline
\end{tabular}




\begin{tabular}{|c|c|c|c|c|c|c|c|c|c|}
\hline 19. & Madhu B $^{32}$ & 2019 & $\begin{array}{c}30 \& \\
\text { above }\end{array}$ & $\begin{array}{c}\text { Chamrajnagar, } \\
\text { S.India }\end{array}$ & 415 & NA & NA & NA & $32.2 \%$ \\
\hline 20. & $\begin{array}{c}\text { Sathiyanara- } \\
\text { yanan S }\end{array}$ & 2019 & $\begin{array}{c}18 \& \\
\text { above }\end{array}$ & $\begin{array}{c}\text { Vellore, } \\
\text { TamilNadu }\end{array}$ & 952 & 383 & 569 & NA & $16.7 \%$ \\
\hline 21. & KshtriyaGK $^{34}$ & 2019 & $20-60$ & NA & 1431 & 705 & 726 & NA & $12.6 \%$ \\
\hline
\end{tabular}

NA-Information Not Available.

\section{Prevalence and Incidence of HTN in Tribal Population of India}

Total 21 prevalence studies were included in the review. These studies were published between January 2008 and December 2019. All the studies were cross sectional and showed sample size ranged from 154 to 47401 [Table1]. Information regarding sex and tribes were Not Available (NA) in few studies. Table 1, summarizes the major study characteristics of tribal population including age, sex, place of study and major tribes. Most of the studies were based on the random sampling. Except for one study that included a slightly older age group ( $\geq 30$ years), all other studies included a uniform age group (mostly the adults of above 18 years). Overall prevalence of hypertension in adults using BP criteria $\geq 140 / 90 \mathrm{mmHg}$ among tribal population ranged from $10 \%$ to $50.5 \%$.

The highest prevalence rate $(50.5 \%)$ of hypertension was found in tribes of Car Nicobar islands whereas, lowest (10\%) was found in in tribal populations of West Bengal, Orrisa and Gujrat. In the present review the prevalence rate was higher in men than the women. Hathur et al. found overall prevalence of hypertension as $21.7 \%$ in Jenu Kuruba tribe, which found the prevalence of hypertension was higher (28.2\%) among men than among women (16.5\%). Similar evidences were found by the study of Kumar et.al who found that $32.3 \%$ men and $14.4 \%$ of women are hypertensive. However, some studies have also reported higher prevalence of hypertension in females than the males.

Among males, the lowest rate $(9.2 \%)$ of prevalence of hypertension was found in the Santhal, Oraons, Koras, Bhumis, Bhathudis, Dhodis, Kuknas and Chaudharis tribes residing in states of West Bengal, Odisha and Gujrat ,however, the highest rate of prevalence (57.7\%) was found among the Rang Bhotia tribes of Uttarakhand . Likewise, in females, the lowest rate (6\%) of hypertension prevalence was found in the tribal population of Uttarakhand and the highest rate of prevalence (36\%) was found among the tribes residing in Kerala. In both of these studies, the names of the tribe were not mentioned.

Manimunda et. al. found an increasing trend in the prevalence of hypertension with increasing age among Nicobarese tribe. Similar findings were observed by Hathur et al., who reported that hypertension among Jenu Kuruba tribe of Karnataka.

\section{Discussion}

Studies on the adverse health effects of high Blood Pressure (BP) or hypertension has already been recognized since early part of $19^{\text {th }}$ century $[35,36]$. However, hypertension in tribal population received very little attention prior to 2000, since it was presumed that tribal populations with their customs and characteristics make them less prone to lifestyle diseases like hypertension. Subsequently, a wide range of prevalence of HTN in tribal populations are reported by various studies across the Indian states. However due to the diversity and heterogeneity of distribution of the population, it is very challenging to arrive at a precise prevalence among Indian tribal population. In the present scopic review, the prevalence rate of hypertension varied from $10 \%$ to $50.5 \%$ in tribal population of India.

The prevalence of HTN varies around the world. In tribal people it is also high similar to urban and rural adult population of the country. The prevalence of HTN was also varied from state to state as well, which might be due to various characteristics of these populations. A systematic review by Kearney et al. ${ }^{2}$ reported that the lowest prevalence of HTN was in rural India (3.4\% in men and $6.8 \%$ in women) and the highest prevalence in Poland (68.9\% in men and $72.5 \%$ in women). The prevalence rates in Indian studies were lower than that recorded in Spain by Banegas $(68.3 \%)^{37}$ and in Italy by Modesti et.al. (64.8\%) in their study. ${ }^{38}$ Geographical variation could be the reason for lower HTN in rural India. Komachi and Shimamoto ${ }^{39}$ have shown that migration and urbanization/acculturization cause a rise in BP levels, which is attributed to change in life style. People migrate to urban areas in search of opportunities and better livelihood. This rural-to-urban migration has resulted in large scale demand for housing, protected water supply, sanitation, health services, and other public utilities. Inadequate provision of these facilities has resulted in unhygienic condition, dilapidated housing, lack of basic amenities, poverty, and filth. All these factors indicate that the quality of living conditions is no better in these socially disadvantaged urban areas than in rural villages. McGarvey and Baker ${ }^{40}$ suggested that selective migration and a form of bio-cultural adaptation to the modern environment may occur. They also suggested that there might be a limit on 
the extent to which participation in a modern life style is associated with higher blood pressure levels.

National Nutrition Monitoring Bureau (NNMB) Tribal Survey-2008-09 conducted by the ICMR - National Institute of Nutrition, Hyderabad found the overall prevalence of hypertension among tribal adults as $24 \%$ (men $25 \%$, women $23 \%$ ), which is near to our findings. ${ }^{41}$ Kokiwar et al.in their study found the prevalence of hypertension as $19.04 \%$ in rural central India. ${ }^{42}$ While Rizwan et al. in their meta-analysis found the pooled estimate of prevalence of hypertension as $16.1 \% .{ }^{43}$ In the present study Hathur et al. conducted a study in Jenu Kuruba tribe and found overall prevalence of hypertension as $21.7 \% .{ }^{17}$ The highest prevalence of hypertension (50.5\%) was found among the Nicobarese tribe in Car Nicobar Islands, ${ }^{15}$ whereas the lowest was reported by Kshatriya et al. in the tribes of West Bengal, Odisha and Gujarat. ${ }^{23}$ Similar study was reported by Mukhopadhyay et al. ${ }^{44}$ who found remarkably high prevalence of definite, as well as borderline, hypertension among Lepchas of the Himalayas where approximately $34 \%$ of women and $45.3 \%$ of men. These high prevalence rates have been attributed to the regular use of millet beer in often large quantities and the regular inclusion of black tea with salt in the diet of the Lepchas. The relationship between salt intake and hypertension was established almost 60 years, ${ }^{45,46}$ back which applies to tribal population also. ${ }^{47}$ Chakma et.al have observed a higher prevalence of hypertension among those who consume salt $>10 \mathrm{~g} / \mathrm{per}$ day, which indicates a positive association of salt intake with hypertension; as the mean salt intake increases blood pressure levels also increase. ${ }^{26}$ Many other studies have also provided similar evidence that greater salt consumption is associated with higher levels of blood pressure. ${ }^{48,49}$ According to a study by Hazarika et al. ${ }^{50,51}$ the added salt in the tea and local alcohol consumption are significant risk factors of HTN among tea garden workers of Assam. Similar evidences had also been obtained among the Solomon Islanders tribes. These tribes lived away from the coast and had a salt intake below $2 \mathrm{~g} /$ day, only $1 \%$ of the population had a raised blood pressure level. In two other tribes with salt intakes between 3 and $8 \mathrm{~g} /$ day, $3 \%$ of the population had a raised levels of blood pressure. In a tribe, which lived on the coast and had a salt intake between 9 and $15 \mathrm{~g} /$ day, $8 \%$ of the population had a raised levels of blood pressure..$^{52}$

In the present research we tried to study several factors that are affected hypertension. A few factors such as sex, age and region were studied with hypertension. However, these important factors affect prevalence and need explanation. Majority of the studies shows that prevalence of hypertension has association with the gender. In the present study the prevalence of hypertension was higher among males than the females, which is similar to findings of other studies carried out in adult population of rural and urban areas. According to Kumar et al.(2016), 32.3\% men and $14.4 \%$ of women were found to be hypertensive. ${ }^{21}$ Hathur et al. studied hypertension among Jenu Kuruba tribe and found that the prevalence of hypertension was higher among men (28.2\%) than among women (16.5\%). ${ }^{17}$ Sharma et.al. found higher prevalence of hypertension and pre-hypertension in males in a rural population in Madhya Pradesh..$^{53}$ According to Gupta et al. (2004), among the rural populations, hypertension prevalence is $24 \%$ among men and $17 \%$ among women. ${ }^{54}$ However there are some findings which shows the higher prevalence of hypertension among females than the males. ${ }^{14,21,31}$ Similar studies were also reported by Kusuma et.al (2004) where the overall prevalence of hypertension ranged from $7.83 \%$ (Khondh men) to $32.43 \%$ (Valmiki women) which indicated that the risk of hypertension escalates after the age of 44 years, and that the risk is relatively greater for women, suggesting some biological basis for gender bias. ${ }^{55,56}$ This could be attributed to the cardio-protective effect of higher circulating female hormone levels (particularly estrogens), which have been linked to a less atherogenic lipid profile in younger women. Higher atherogenic lipid profile, greater arterial distensibility, increased adiposity and obesity, and possibly changes in body fat distribution toward a more centripetal pattern, have all been implicated in this increased risk of hypertension among older women. Schall also reported that even in Pacific populations with more traditional lifestyles and low rates of hypertension, older women have higher BP levels than do older men, but explained that in traditional societies, body weight and mass decline with age. ${ }^{57}$

Several researchers reported that among adults, primarily in developed countries, BP increases with advancing age, and the increase is particularly steep among women, to the extent that BP levels (especially SBP) among menopausal women exceed those among men. ${ }^{58,59}$ Similar study is reported by Manimunda et al., who found an increasing trend in the prevalence of hypertension with increasing age among Nicobarese tribe. ${ }^{15}$ Similar trend was also reported by Hathur et al. among Jenu Kuruba tribes. ${ }^{17}$ These studies are also similar with other studies. ${ }^{20}$ According to the Non-Communicable Disease Risk Factor Survey (2007-08) - Madhya Pradesh, the overall prevalence of hypertension among rural population was $20 \%$ and the prevalence was increased with age (11\% in $15-24$ years to $43 \%$ in $55-64$ years). ${ }^{60}$ Similar findings were reported by Patel et al. who found that as the age increased, the prevalence of hypertension also increased. With the advance in age from 28 to 49 years, the prevalence was higher in men and, afterwards, the women took over. ${ }^{61}$ Haldiya et al. also reported that the prevalence of hypertension was increasing with increase in the age. ${ }^{62}$ Increase in BP with age was also reported in studies from other parts of the world. ${ }^{63}$ 
A remarkably higher prevalence of hypertension and increasing BP along with age confirms the well-established phenomenon that high $\mathrm{BP}$, and increasing BP levels with age, accompany the process of modernization. Age probably represents an accumulation of environmental influences and the effect of genetically programmed senescence in body systems. ${ }^{64}$

Smoking and diabetes mellitus were also reported as the risk factors of hypertension among 4955 individuals in rural Kerala. ${ }^{65}$ Similar studies were also reported by Radhakrisnan et.al where smoking was the only modifiable risk factor, which had shown significant association with hypertension and the family history of hypertension, which was a nonmodifiable risk factor had also shown a statistical significant association for hypertension in both males and females. ${ }^{66}$ The impacts of alcohol and smoking on diabetes have been discussed by many studies ${ }^{67,68}$ and it was found to be same in our study particularly among males. Family history of diabetes ${ }^{69}$ was found to be a strong factor in both males and females among the various other factors, which influences the prevalence of diabetes and the findings is in par with various other studies.

\section{Conclusion}

This scoping review revealed that varied prevalence of hypertension in adult tribal population of India which is similarly to the prevalence observed in urban and rural population and also in both genders. Thus, we can conclude that the tribal are the also venerable to non-communicable diseases like hypertension and they require the urgent implementation of strategies to prevent and manage hypertension.

\section{Conflicts of Interest: None \\ References}

1. Gupta R. Trends in hypertension epidemiology in India. J Hum Hypertens 2004; 18: 73-78. DOI:10.1038/ sj.jhh.1001633.

2. Kearney PM, Whelton M, Reynolds K, Muntner $\mathrm{P}$, Whelton PK, He J. Global burden of hypertension: analysis of worldwide data. Lancet 2005; 365(9455): 217-223.

3. Ezzati M, Lopez AD, Rodgers A, Vander HS, Murray CJ. Selected major risk factorsand global and regional burden of disease. Lancet 2002; 360(9343): 1347-1360.

4. Gupta R, Sharma AK, Gupta VP et al. Increased variance in blood pressure distribution and changing hypertension prevalence in an urban Indian population. J Hum Hypertens 2003; 17: 535-540. DOI:10.1038/sj.jhh.1001588.

5. Gupta SP, Siwach SB, Moda VK. Epidemiology of hypertension-based on total community survey in the rural population of Haryana. Indian Heart J. 1977;

\section{9: 53-62.}

6. Gupta R, Sharma AK. Prevalence of hypertension and subtypes in an Indian rural population: clinical and electrocardiographic correlates. J Human Hypertens 1994; 8: 823-829.

7. Malhotra P, Kumari S, Kumar R et al.Prevalence and determinants of hypertension in an un-industrialized rural population of North India. J Human Hypertens 1999; 13: 467-472. DOI:10.1038/sj.jhh.1000864.

8. Kshatriya GK. Changing Perspectives of Tribal Health in the Context of Increasing Lifestyle Diseases in India. J Environ Soc Sci 2014; 1(1): 101.

9. Rizwan SA, Kumar R, Singh AK, Kusuma YS, Yadav K, et al. Prevalence of Hypertension in Indian Tribes: $A$ Systematic Review and Meta-Analysis of Observational Studies. PLOS ONE 2014; 9(5): e95896.

10. Census of India. Population enumeration data (final population) 2011. New Delhi: Registrar General of India and Census Commissioner; 2011. Available from: http://www.censusindia.gov.in/2011census/ population_enumeration.html [Google Scholar].

11. Bisai S, Saha KB, Sharma RK et al.An overview of tribal population in India. Tribal Health Bull 2014; 20 : 1-122. Available from: http://www.nirth.res.in/publications/ tribal_health_bulletin/thb_special_issue2014.pdf.

12. Moher D, Liberati A, Tetzlaff J, Altman DG, The PRISMA Group. Preferred reporting items for systematic reviews and meta-analyses: the PRISMA statement.PLOS Medicine2009; 6:e1000097.

13. Liberati A, Altman DG, Tetzlaff J, Mulrow C, Gøtzsche PC, Ioannidis JP et al. The PRISMA statement for reporting systematic reviews and meta-analyses of studies that evaluate health care interventions: explanation and elaboration. PLoS Medicine 2009; 6: e1000100.

14. Tiwari RR. Hypertension and epidemiological factors among tribal labour population in Gujarat. Indian Journal of Public Health 2008; 52(3): 144-146.

15. Manimunda SP, Sugunan AP, Benegal V, Balakrishna N, Rao MV, Pesala KS. Association of hypertension with risk factors and hypertension related behaviour among the aboriginal Nicobarese tribe living in Car Nicobar Island, India. Indian J Med Res 2011; 133: 287-293.

16. Meshram, Arlappa N, Balkrishna N, Rao KM, Laxmaiah A, Brahmam GNV. Prevalence of hypertension, its correlates and awareness among adult tribal population of Kerala state, India. J Postgrad Med 2012; 58(4): 255-261.

17. Hathur B, Basavegowda M, Ashok NC. Hypertension: An emerging threat among tribal population of Mysore; JenuKuruba tribe diabetes and hypertension study. Int J Health Allied Sci 2013; 2: 270-274.

18. Meshram II, Laxmaiah A, Mallikharjun RK et al. Prevalence of hypertension and its correlates among 
adult tribal population ( $\geq 20$ years) of Maharashtra State, India. Int J Health Sci Res 2014; 4(1): 130-139.

19. Misra PJ, Mini GK, Thankappan KR. Risk factor profile for non-communicable diseases among Mishing tribes in Assam, India: Results from a WHO STEPs survey. Indian J Med Res 2014; 140: 370-378.

20. Laxmaiah A, Meshram II, Arlappa N et al. Socioeconomic \& demographic determinants of hypertension and knowledge, practices \& risk behaviour of tribals in India. Indian J Med Res 2015; 141: 697-708. DOI:10.4103/0971-5916.159592.

21. Kumar RK, Tyagi AR, Tiwari R, Rai N. Study of hypertension among tribal adults in a block of Mandla district, Madhya Pradesh, India. Int J Community Med Public Health 2016; 3(5): 1033-1037.

22. Kandpal V, Sachdeva MP, Saraswathy KN. An assessment study of CVD related risk factors in a tribal population of India. BMC Public Health 2016; 16: 434.

23. Raina SK, Chander V, Prasher CL and Raina S. Prevalence of Hypertension in a Tribal Land LockedPopulation at High Altitude. Hindawi Publishing Corporation. Scientifica; Volume 2016, Article ID 3589720, 8 pages; http://dx.doi.org/10.1155/2016/3589720.

24. Negi PC, Chauhan R, Rana V, Vidyasagar, Lal K. Epidemiological Study of Non-Communicable Diseases (NCD) Risk Factors in Tribal District of Kinnaur, HP: A Cross-Sectional Study. Indian Heart J 2016; 68(5): 655662. DOI: 10.1016/j.ihj.2016.03.002. Epub 2016 Mar 29.

25. Kshatriya GK, Acharya SK. Triple Burden of Obesity, Undernutrition, and Cardiovascular Disease Risk among Indian Tribes.PLoS One 2016; 11(1): e0147934. DOI: 10.1371/journal.pone.0147934. eCollection 2016.

26. Chakma T, Kavishwar A, Sharma RK, Rao PV. High prevalence of hypertension and its selected risk factors among adult tribal population in Central India. Pathogens and Global Health 2017; 111(7): 343-350. https://doi.org/10.1080/20477724.2017.1396411.

27. Deo MG, Pawar PV, Kanetkar SR, KakadeSV. Prevalence and risk factors of hypertension and diabetes in the Katkari tribe of coastal Maharashtra. J Postgrad Med 2017; 63(2): 106-113. DOI: 10.4103/0022-3859.194204.

28. Sajeev P, Soman B. Prevalence of noncommunicable disease risk factors among the Kani tribe in Thiruvananthapuram district, Kerala. Indian Heart J 2018; 70(5): 598-603. DOI: 10.1016/j.ihj.2018.01.022. Epub 2018 Jan 11.

29. Tushi A, Rao SR, Pattabi K, Kaur P. Prevalence of risk factors for non-communicable diseases in a rural tribal population of Mokokchung, Nagaland, India. Natl Med J India 2018; 31(1): 11-14. DOI: 10.4103/0970258X.243405.

30. Deo MG, Pawar PV, Kanetkar SR, Kakade SV. Multicentric study on prevalence and risk factors for hypertension and diabetes in tribal communities in Western and Northern Maharashtra. J Postgrad Med 2018; 64(1): 23-34. DOI: 10.4103/jpgm.JPGM_245_17.

31. Kshatriya GK, Acharya SK. Prevalence and risks of hypertension among Indian tribes and its status among the lean and underweight individuals. Diabetes MetabSyndr 2019; 13(2): 1105-1115. DOI:10.1016/j. dsx.2019.01.028. Epub 2019 Jan 22.

32. Madhu B, Prathyusha K, Prakruthi P, Srinath KM. Comparison of prevalence of life style risk factors and 10 year risk of CVD event among rural and tribal population of Kollegal Taluk, Chamrajanagar district, South India.Diabetes Metab Syndr 2019; 13(5): 29612966. DOI: 10.1016/j.dsx.2019.07.056. Epub 2019 Aug 2.

33. Sathiyanarayanan S, Muthunarayanan $L$, Devaparthasarathy TA. Changing Perspectives in Tribal Health: Rising Prevalence of Lifestyle Diseases among Tribal Population in India. Indian J Community Med 2019; 44(4): 342-346. DOI: 10.4103/ijcm.IJCM_40_19.

34. Kshatriya GK, Kumari A, Acharya SK. Comparing the ability of anthropometric indicators in determining the prevalence of hypertension among Indian tribes. Diabetes Metab Syndr 2019; 13(1): 696-706. DOI: 10.1016/j.dsx.2018.11.038. Epub 2018 Nov 19.

35. Hay J. A British Medical Association Lecture on the significance of a raised blood pressure. BMJ 1931; 2: 43-47.

36. Weiss S, Ellis L.The rational treatment of arterial hypertension. JAMA 1930; 95: 846-852.

37. Banegas JR, Rodríguez-Artalejo F, Ruilope LM et al. Hypertension magnitude and management in the elderly population of Spain. J Hypertens 2002; 20: 2157-2164.

38. Modesti PA, Calabrese PA. Marzotti M Bing I.Malandrino H. Boddi D M et.al. Prevalence, Awareness, Treatment, and Control of Hypertension among Chinese FirstGeneration Migrants and Italians in Prato, Italy: The CHIP Study. 2017 | Article ID 6402085 | 8 pages | https://doi. org/10.1155/2017/6402085.

39. Komachi Y, Shimamoto T. Regional differences of blood pressure and its nutritional background in several Japanese populations. In: Kesteloot H, Joossens JV, eds. Epidemiology of Arterial Blood Pressure. The Hague: Martinus Nijnoff Publishers; 1980: 457-472.

40. Mc Garvey ST, Baker PT. The effects of modernization and migration on Samoan blood pressure. Hum Biol 1979; 51: 461-479.

41. NNMB Tribal Survey. Technical Report, National Institute of Nutrition, ICMR, 2008-09; Hyderabad.

42. Kokiwar P, Gupta S. Prevalence of hypertension in a rural community of central India. Int J Biol Med Res 2011; 2(4): 950-953. 
43. Rizwan SA.Hypertension in Indian Tribes. PLOS ONE www.plosone.org. 2014; 9(5): e95896. Accessed on $8^{\text {th }}$ April 2015.

44. Mukhopadhyay B, Mukhopadhyay S, Majumder PP. Blood pressure profile of Lepchas of the Sikkim Himalayas: epidemiological study. Hum Biol 1996; 68: 131-145.

45. Dahl LK, Lover RA. Evidence for a relationship between sodium intake and human essential hypertension. Arch Intern Med 1954; 94: 525-531. DOI: 10.1001/archinte. 1954.00250040017003

46. Sasaki N. The relationship of salt intake to hypertension in the Japanese. Geriatrics 1964; 19: 735-744.

47. Laxmaiah A, Meshram II, Arlappa N et al. Socioeconomic \& demographic determinants of hypertension and knowledge, practices \& risk behaviour of tribals in India. Indian J Med Res 2015; 141: 697-708. DOI:10.4103/0971-5916.159592.

48. Prior IA, Evans JG, Harvey HP et al. Sodium intake and blood pressure in two Polynesian population. $N$ Engl J Med 1968; 279: 515-520. DOI:10.1056/NEJM1 96809052791004.

49. Joossens JV, Willems J, Claessens J et al. Sodium and hypertension In: Fidanza F, Keys A, Ricci G, Somogyi JC, editors. Nutrition and cardiovascular diseases. Rome: Morgagni Edizioni Scientifiche; 1971; 91-110.

50. Hazarika NC, Narain K, Biswas D, Kalita HC, Mahanta J. Hypertension in the native rural population of Assam. Natl Med J India 2004; 17(6): 300-304.

51. Hazarika NC, Biswas D, Narain K, Kalita HC, Mahanta J. Hypertension and its risk factors in tea garden workers of Assam. Natl Med J India 2002; 15(2): 63-68.

52. Page LB, Damon A, Moellering RC. Jr Antecedents of cardiovascular disease in six Solomon Islands societies. Circulation 1974; 49: 1132-1146.

53. Sharma A, Gupta SK, Agarwal SS, Gupta M, Shrivastava S. A study of prehypertension \& hypertension and its associated risk factors in a rural area of Madhya Pradesh. Natl J Community Med 2015; 6(2).

54. Gupta R. Trends in hypertension epidemiology in India. Journal of Human Hypertension 2004; 18: 73-78.

55. Kusuma YS, Bontha BV, Naidu JM. Prevalence of hypertension in some cross-cultural populations of Visakhapatnam district, South India. Ethnicity \& Disease 2014; 14: 250-259.

56. Kusuma YS, Bontha BV, Naidu JM Blood pressure levels among cross-cultural populations of Visakhapatnam district, Andhra Pradesh, India. Annals of Human Biology 2002; 29(5): 502-512.

57. Schall Jl. Sex differences in the response of blood pressure to modernization. Am J Hum Biol 1995; 7: 159-172.

58. Kannel WB, Doyle JT, Ostfelt AM et al. Optimal resources for primary prevention of atherosclerotic diseases. Report of Intersociety Commission for Heart Disease Resources. Circulation 1984; 70: 115A-205A.

59. Williams EL, Winkleby MA, Fortmann SP. Changes in coronary heart disease risk factors in the 1980s: evidence of a male-female crossover effect with age. Am J Epidemiol 1993; 137: 1056-1067.

60. Integrated Disease Surveillance Project (IDSP).NonCommunicable Disease Risk Factors Survey. MP-IDSPNDC. 2005-06.ICMR.

61. Patel P, Gupta PK, White CM, Stanley AG, Williams $B$, Tomaszewski M. Screening for non-adherence to antihypertensive treatment as a part of the diagnostic pathway to renal denervation. J Hum Hypertens 2016; 30: 368-373.

62. Haldiya KR, Sachdev R, Mathur ML, Lal SJ. Epidemiology of essential hypertension in arid population of Rajasthan. Annual Report 2005-06.

63. Bansal SK, Saxena V, Kandpal SD, Gray WK, Walker WR, Goel D. The prevalence of hypertension and hypertension risk factors in a rural Indian community: A prospective door-to-door study. J Cardiovasc Dis Res 2012; 3(2): 117-123. DOI: 10.4103/0975-3583.95365.

64. Mohan V, Deepa M, Farooq S, Datta M, Deepa R. Prevalence, awareness and control of hypertension in Chennai - The Chennai Urban Rural Epidemiology Study (CURES-52). J Assoc Physicians India 2007; 55: 326-332.

65. Thankappan KR, Sivasankaran S, Sarma PS, Mini G, Khader SA, Padmanabhan P et al. Prevalence-correlatesawareness-treatment and control of hypertension in Kumarakom, Kerala: baseline results of a communitybased intervention program. Indian Heart J 2006; 58(1): 28-33.

66. Radhakrishnan S, Ekambaram M. Prevalence of diabetes and hypertension among a tribal population in Tamil Nadu. Archives of Medicine and Health Sciences 2015; 3(1): 66-71.

67. Barnard ND, Cohen J, Jenkins DJ, Turner-McGrievy G, Gloede L, Jaster B et al. A low-fat vegan diet improves glycemic control and cardiovascular risk factors in a randomized clinical trial in individuals with type 2 diabetes. Diabetes Care 2006; 29: 1777-1783.

68. Robbins JM, Vaccarino V, Zhang H, Kasl SV. Socioeconomic status and type 2 diabetes in African American and non- Hispanic white women and men: Evidence from the Third National Health and Nutrition Examination Survey. Am J Public Health 2001; 91: 76-83.

69. Joshi SR, Saboo B, Vadivale M, Dani SI, Mithal A, Kaul $U$ et al. Prevalence of diagnosed and undiagnosed diabetes and hypertension in India - Results from the Screening India's Twin Epidemic (SITE) study. Diabetes Technol Ther 2012; 14: 8-15. 